\title{
Pola Laporan Keuangan wirausahawan di Indonesia
}

\section{Tedy Ardiansyah}

Universitas Indraprasta PGRI Jakarta, tedyardiansy4h@gmail.com

\section{ARTICLES INFORMATION}

ABSTRACT

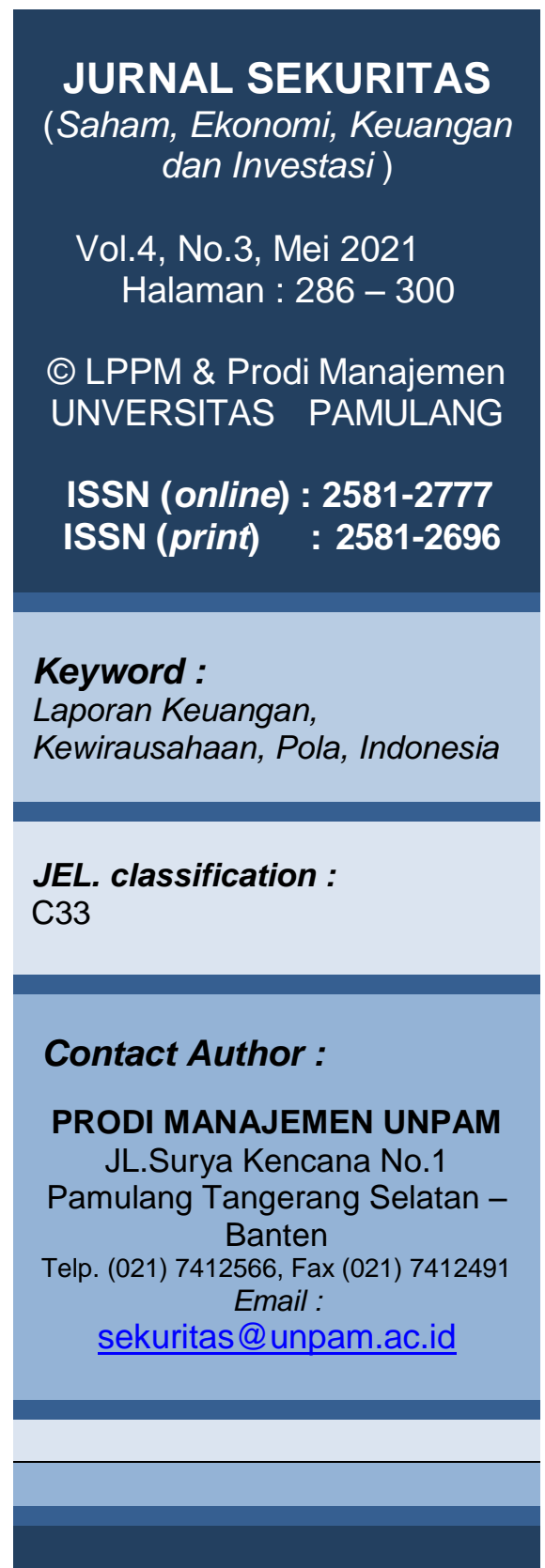

Penelitian ini bertujuan untuk mengetahui model atau pola laporan keuangan wirausaha di Indonesia dimana saat ini belum dapat diketahui model kebijakan laporan keuangan yang tepat dalam mendukung Kewirausahaan di Indonesia. Penelitian ini menggunakan metode penelitian kualitatif deskriptif yaitu metode untuk memahami berbagai konsep yang ditemukan dalam proses penelitian, dengan teknik analisis isi dan riset kepustakaan serta didukung dengan tools analisis untuk kualitatif yaitu NVIVO 12. Hasil penelitian menunjukkan ada 4 bagian yang menjadi garis besar dari penelitian ini yaitu Cluster Analysis membantu dalam menentukan korelasi data yang kuat, Project Map Hasil membentuk model baru tentang hasil laporan keuangan dan kinerja UMKM, Project Map Hasil lain membentuk model adanya variabel baru yang membantu dalam mendukung kesuksesan laporan keuangan dengan kinerja UMKM dan terkahir Project Map Future dimana membentuk pola baru terutama mengenai effect atau akibat hasil dari laporan keuangan dan kinerja UMKM yaitu effect yang mendukung dan effect yang bermasalah.

This study aims to determine the model or pattern of entrepreneurship financial statements in Indonesia where currently the appropriate financial statement policy model in supporting entrepreneurship in Indonesia is not known. This study uses descriptive qualitative research methods, namely methods to understand various concepts found in the research process, with content analysis techniques and library research and is supported by analytical tools for qualitative, namely NVIVO 12. The results show that there are 4 parts that are the outlines of this research. namely Cluster Analysis helps in determining a strong data correlation, Project Map Results form a new model of financial report results and MSME performance, Project Map Other results form a model for new variables that help support the success of financial reports with MSME performance and finally Project Map Future where form a new pattern, especially regarding the effects or consequences of the results of financial reports and the performance of MSMEs, namely the supportive effect and the problematic effect. 


\section{A. PENDAHULUAN}

Indonesia merupakan negara berkembang dan tidak terpisahkan dengan kegiatan usaha yang dilakukan oleh usaha kecil dan menengah (UMKM). Usaha mikro adalah perusahaan yang sebagian besar dipimpin oleh Indonesia, dengan UMKM saat ini sangat dibutuhkan dalam mendukung atau daya guna penciptaan lapangan kerja, membantu pemerintah dalam menurunkan tingkat pengangguran saat ini. Kegiatan UMKM tidak dapat dipisahkan dari sejumlah kegiatan akuntansi yang sangat penting yang membantu untuk mewakili pertumbuhan dan posisi keuangan UMKM. Oleh karena itu, semua bentuk kegiatan dicatat dan digunakan untuk evaluasi.

Sebuah usaha mikro, SME adalah perusahaan ekonomi yang menghasilkan barang dan jasa dengan total aset dan omset tahunan tertentu. UMKM adalah UMKM dimana dapat menyediakan lapangan kerja dan berperan dalam pemerataan dan pertumbuhan pendapatan orang dan mengupayakan economy growth serta mendukung melaksanakan stabilitas nasional. Untuk menghadapi Masyarakat Ekonomi ASEAN (MEA) 2015, UMKM Indonesia harus mampu berkompetisi dengan baik dan good quality itu sendiri dan merebut semua peluang yang ada untuk bertahan dalam perekonomian nasional.

Kinerja UMKM juga dipengaruhi oleh kewirausahaan. Bakat wirausaha berkualitas tinggi dapat berdampak pada kelangsungan bisnis yang dimiliki, sehingga penting untuk mengembangkan talenta. Agen penjualan yang kompeten dan giat dapat mendongkrak bisnis mereka dengan menciptakan inovasi baru dan inovatif.

UMKM merupakan wadah orang menggantungkan penghidupan mereka dan berkontribusi pada keberhasilan, meningkatkan kinerja UMKM sangat berkaitan dengan peningkatan kebahagiaan masyarakat. UMKM dalam persaingan yang semakin ketat dalam dunia bisnis. Tingkat kinerja yang dicapai oleh UMKM tersebut menunjukkan betapa efektifnya UMKM dalam memadukan keekonomian UMKM tersebut. Meski UMKM berperan strategis, mengembangkan kinerja UMKM bukanlah tugas yang mudah. Kesulitan dalam mengukur kinerja adalah salah satu dari kendala bagi pengusaha untuk mengukur kinerja. Memang, pengusaha UMKM fokus pada kegiatan operasi, sehingga catatan akuntansi dan laporan keuangan sering terabaikan. Tanpa catatan akuntansi dan good financial report, tidak mudah menilai kinerja UMKM.

Pemilik UMKM yang mengelola usaha sering mengalami kesulitan untuk mendokumentasikan apa yang terjadi pada usaha di Banyak pemilik UMKM tidak mengikuti pedoman pelaporan keuangan berdasarkan prinsip akuntansi keuangan, dan ketidakpatuhan terhadap petunjuk penerimaan/penerbitan dari, batas waktu/kredit dari, pembelian/penjualan Hanya jumlah produk yang dicatat. Jadi mempersulit mereka untuk mengukur, dan membuktikan bahwa kinerja mereka bagus.

Setiap perusahaan perlu memiliki neraca untuk menganalisis kinerja keuangannya. Hal ini memungkinkan memberikan informasi tentang status keuangan, produktivitas/kinerja, dan arus kas operasi untuk membantu pengambilan keputusan keuangan. Pengusaha bijaksana untuk mengirim uang ke untuk mengembangkan bisnis mereka, karena memiliki data keuangan yang baik. Agar berhasil dalam bisnis, Anda perlu menyimpan catatan transaksi, manajemen keuangan, dan manajemen kredit dari laporan keuangan Anda.

Tingginya potensi UMKM untuk pengembangan ekonomi tidak sebanding dengan kualitas UMKM. Registrasi dan pengelolaan keuangan adalah bagian dari beberapa bentuk keberhasilan UMKM. Masalah mendasar bagi UMKM yaitu dalam proses mulai mencatat sampai sususnan pada laporan keuangan yang tidak memadai. Faktanya, UMKM terkendala oleh banyak faktor, antara lain tidak pahamnya bagaiman laporan keuangan yang baik. Laporan UMKM biasanya hanya mencatat jumlah barang yang diterima dan diberikan, dari sejumlah catatan produk/ barang dibeli serta dijual, jumlah kredit, dan hutang dagang, tanpa menggunakan standar akuntansi. Informasi yang sebenarnya. Karena informasi akuntansi 
yang diperoleh berguna untuk pengambilan keputusan, pertimbangan dasarnya adalah:

Membeli bahan baku dan peralatan manufaktur, menetapkan harga, mengajukan permintaan pinjaman bank, mengembangkan bakat dan menambah properti komersial. Pemangku kepentingan UKM perlu memahami dan memahami seperti apa sistem akuntansi, apa yang harus disiapkan dan bagaimana menerapkan skema pengumpulan data akuntansi untuk membuat neraca. Ideal. Financial Report adalah final result dari akuntansi diperlukan dari bagian - bagian yang membutuhkan laporan terebut. Untuk mencapai situasi dan situasi tersebut, perlu dilakukan inovasi dalam penyusunan anggaran agar selaras dengan Standar Akuntansi Keuangan (SAK).

Menurut Hendrati, (2010), kualitas tenaga kerja yang tercermin dari pelatihan dan kewirausahaan sebesar berpengaruh dihadapkan Financial Performance UMKM. Sebuah studi oleh Harahap (2014) meneliti kemampuan UMKM membentuk susunan laporan keuangan serta dampaknya terhadap kinerja UMKM. menemukan bahwa kemampuan pelaporan keuangan UMKM tidak mempengaruhi kinerja UMKM yang didukung oleh lembaga usaha. Hasilnya adalah merupakan asumsi bahwa SDM akan meningkatkan kinerja. memprioritaskan pengalaman dan komitmen daripada pembuatan laporan keuangan sebagai bukti kinerja. Hendrati (2010) menyelidiki dampak pendidikan, pelatihan dan pengusaha dihadakan pada financial performance UMKM. Survey diadakan pada UMKM Ikat di Kecamatan Bandarkidur Kecamatan Mojorot Kota Kediri.Hasil penelitian menunjukkan bahwa pendidikan, pelatihan dan usaha berkorelasi dengan financial report UMKM

Dari Bentuk permasalahan diatas, maka peneliti menarik untuk melakukan riset yang menyangkut laporan keuangan dan Kewirausahaan dimana masalah yang muncul selalu berbeda dengan apa yang dilakukan oleh wirausahawan, untuk itu peneliti berminat untuk menuliskan paper berjudul "Pola Laporan Keuangan Kewirausahaan di Indonesia".

\section{B. KAJIAN LITERATUR}

\section{Standar Laporan Keuangan UMKM}

Standar Laporan Keuangan UMKM Usaha Mikro Kecil danMenengah (UMKM) Tujuan utama laporan keuangan adalah untuk menyediakan informasi mengenai posisi keuangan, kinerja, dan perubahan posisi keuangan suatu perusahaan yang berguna bagi sejumlah besar pemakai dalam pengambilan keputusan ekonomi. Akuntan menyiapkan laporan keuangan untuk pengguna laporan keuangan - mulai dari manajemen perusahaan, otoritas pajak, hingga calon investor - membutuhkan akses ke laporan keuangan. Laporan tersebut diharapkan dapat memberikan gambaran yang andal dan bermanfaat tentang keuangan organisasi, yang dibuat sesuai dengan standar yang dikembangkan oleh profesi akuntansi. Standar UKM menentukan bahwa Laporan keuangan minimum terdiri dari laporan posisi keuangan (neraca), laporan laba rugi periode berjalan, catatan atas laporan keuangan.

1. Neraca Neraca adalah ringkasan posisi keuangan, yang meliputi aset, hutang, dan modal pada tanggal tertentu, misalnya akhir semester, akhir tahun. Neraca, atau laporan posisi keuangan, menyajikan potret sumber daya (aset) perusahaan dan klaim atas sumber daya ini (kewajiban) dan ekuitas pemegang saham pada tanggal tertentu. Neraca terdiri dari tiga komponen, yaitu aset, kewajiban, dan modal.

2.Laporan Laba Rugi Laporan laba rugi merangkum pendapatan dan beban serta keuntungan dan kerugian. Ada beberapa komponen utama dalam laporan laba rugi, termasuk pendapatan, beban, dan laba rugi. Posisi laba rugi dapat dilihat dari perbandingan jumlah pendapatan yang diperoleh dengan beban biaya yang dikeluarkan oleh perusahaan. Jika total pendapatan perusahaan lebih besar dari total biaya, perusahaan berada dalam posisi laba. Namun sebaliknya, jika total pendapatan perusahaan lebih kecil dari biaya keseluruhan, maka perusahaan tersebut merugi.

3.Catatan atas Laporan Keuangan Laporan ini memuat kebijakan akuntansi yang signifikan, dan mengklarifikasi informasi lain, misalnya informasi tentang jenis metode penyusutan yang digunakan, piutang tak tertagih, sengketa aset dalam proses litigasi, 
alasan perubahan metode penyusutan.

\section{Laporan Keuangan dan Kewirausahaan}

Keputusan yang baik oleh UMKM bergantung pada akses informasi keuangan yang akurat, konsisten, dan andal yang memberikan wawasan tentang dampak skenario alternatif (Shields \& Shelleman, 2011). Kualitas laporan keuangan dan kesesuaian analisis yang dihasilkan menentukan efektivitas keputusan(Carraher \& H, 2013).

Laporan keuangan yang andal dan keputusan yang efektif sangat penting bagi UKM karena akses mereka yang terbatas ke sumber daya keuangan. Keputusan yang buruk dengan cepat dapat menyebabkan likuiditas, gangguan operasional, dan ketidakmampuan untuk mengejar peluang pasar ((Carraher \& $\mathrm{H}, 2013)$. Informasi keuangan yang baik sangat penting, karena pengusaha sering mengandalkan bias mereka untuk membuat keputusan, yang menyebabkan kesalahan keputusan yang merugikan bisnis. Bias dapat menyederhanakan situasi dan memungkinkan keputusan dalam situasi di mana pemilik kekurangan atau tidak dapat memahami semua informasi yang diperlukan. Oleh karena itu, pemilik bisnis biasanya mengalami kesenjangan pengetahuan, karena mereka tidak menyadari atau mengetahui tentang dampak keuangan dari keputusan mereka. Kesenjangan ini dapat sangat merugikan perusahaan kecil yang tidak menggunakan laporan keuangan, karena kurangnya informasi keuangan, informasi yang salah. atau penggunaan informasi yang salah dengan mudah dapat mengakibatkan likuiditas, kesulitan keuangan, atau kegagalan. Secara keseluruhan, UMKM dapat menimbulkan risiko bisnis dan keuangan yang tidak perlu yang lebih besar daripada imbalan terkait.

Teori keuangan tradisional mengasumsikan bahwa informasi, termasuk informasi keuangan, tersedia secara bebas dan luas, secara akurat dan cepat ditransmisikan secara transparan kepada pemangku kepentingan (Brigham \& M, 2013). Carraher \& H (2013) dan Shields \& Shelleman (2011)juga menekankan bahwa UMKM harus memiliki informasi yang andal dan akurat ketika membuat keputusan. Namun arus informasi di antara perusahaan kecil cenderung dibatasi oleh kendala yang muncul dari kualitas informasi yang buruk, kurangnya motivasi dan pengalaman di antara pemilik, sumber daya yang terbatas, dan biaya yang tinggi. Dengan demikian, perusahaan besar cenderung cocok dengan asumsi teori keuangan daripada UMKM swasta kecil.

Laporan keuangan mewakili sumber informasi yang kuat dan sangat relevan (Carraher \& $H, 2013)$. Informasi yang terkandung dalam laporan ini menyediakan data yang diperlukan untuk menginformasikan analisis yang akurat dan penting bagi pemilik, investor, dan pemberi pinjaman. Pentingnya mereka sangat jelas dalam kaitannya dengan efek potensial dari keputusan dan manajemen keuangan yang buruk pada perusahaan kecil dan tingkat kegagalannya yang tinggi. Pemilik perusahaan kecil sering tidak memiliki keterampilan bisnis yang kuat dan memiliki pemahaman yang lemah tentang proses untuk membuat laporan keuangan dan menafsirkannya dalam konteks pengambilan keputusan. Selain itu, perusahaan kecil sering kali harus membuat keputusan dalam lingkungan yang tidak pasti, tanpa informasi yang lengkap, yang merupakan ideal yang tidak realistis bagi UMKM

\section{METODOLOGI PENELITIAN}

Pendekatan penelitian menggunakan penelitian kualitatif, Leavy (2017)Penelitian kualitatif sering dicirikan dengan pendekatan induktif untuk menghasilkan pengetahuan yang bertujuan untuk menghasilkan hasil yang bermakna. Peneliti menggunakan pendekatan ini untuk menyelidiki. Menyelidiki dan mempelajari fenomena sosial secara kuat. Temukan makna yang dirasakan orang dalam kaitannya dengan suatu aktivitas, situasi, peristiwa atau hal. Atau mendapatkan pemahaman yang lebih dalam tentang beberapa aspek kehidupan sosial. Nilai inti penelitian kualitatif mencakup pentingnya pengalaman subjektif manusia dan proses menghasilkan makna dan gagasan (yaitu gagasan dari sampel kecil). Penelitian 
kualitatif seringkali tepat bila tujuan utamanya adalah penemuan, penjelasan atau penjelasan.

Survei dilakukan dengan menggunakan teknik sampling probabilistik, atau sampling rasional. Kumar (2011) Pertimbangan utama dalam memilih sampel untuk tujuan tertentu adalah untuk mengevaluasi apa yang dapat memberikan informasi paling banyak untuk mencapai tujuan penelitian. Siapa yang mungkin memiliki informasi yang dibutuhkan peneliti dan siapa yang bersedia melakukannya? Jenis pengambilan sampel ini membantu menetapkan fakta sejarah, menjelaskan fenomena, dan mengembangkan hal-hal yang kurang diketahui.

Metode tinjauan dokumen secara teoritis cocok untuk masalah yang sedang dipertimbangkan. Secara khusus, ada penelitian tentang konsep-konsep yang digunakan oleh referensi yang ada, terutama artikel dalam buku-buku sains. Tinjauan Pustaka bertujuan untuk merangkum konsep-konsep yang digunakan sebagai dasar pertimbangan dalam penelitian (Wiratna Sujarweni, 2014).

Populasi yang dilakukan adalah berupa paper dari jurnal yang terindeks Nasional atau terindeks Sinta, dimana penelitian dilakukan di jawa dan sumatera dengan rentang waktu antara tahun 2015 sampai dengan tahun 2021

Jumlah paper atau artikel sebanyak 12 dari berbagai jurnal dimana paper atau artikel ini dibuat berdasarkan dari daerah masih-masing yaitu surabaya, semarang, Jakarta, Tasikmalaya, palembang, Bali, Yogyakarta, Lamongan, Tangerang, Kuningan, Bandung dimana ditotalkan ada sebanyak 10 daerah. Masing-masing dari paper akan diberikan kode guna mempermudah dalam proses pemetaan data, Yaitu "S", "SE", "J", "T", "P", "B", "L", "TA", "K" dan "B"yang semuanya itu merupakan akronim dari asal kota mereka.

\section{Pengumpulan Data}

Teknik pengumpulan data yang dilakukan adalah data sekunder yang berasal dari paper atau artikel jurnal dimana data tersebut merupakan data primer dan data sekunder dari data penelitian sebelumnya. Data Penelitian ini merupakan data penelitian dari berbagai daerah di Indonesia dengan rentang waktu dari tahun 2015 sampai tahun 2020 dengan kurun waktu sebanyak 6 tahun.

\section{Teknik analisis data}

Analisis data yang dilakukan antara lain Cluster Analysis dan Project Map. Cluster Analysis merupakan analisis untuk melakukan uji data dari sejumlah penulis dimana akan memastikan bahwa data yang dilakukan merupakan data yang mempunyai korelasi antara penulis satu dengan yang lainnya. Kemudian untuk Project Map adalah bentuk model yang akan dihasilkan dari uji yang dilakukan dari beberapa paper atau artikel sebanyak 12 dari 10 daerah yang berada di Indonesia

\section{Alat Analisis}

Alat analisis yang digunakan berupa alat uji kualitatif yang teruji yaitu NVIVO seri 12 , dimana alat ini sangat membantu dalam melakukan kajian terhadap uji yang dilakukan terhadap data-data yang akan diolah sehingga mempermudahkan peneliti untuk melakukan suatu keputusan dari hasil penelitian yang akan dilakukan. 


\section{HASIL DAN PEMBAHASAN}

Beberapa paper atau artikel dari beberapa jurnal dibuatkan dalam matriks sebagai berikut, antara lain

Tabel 1. Perbandingan Jurnal

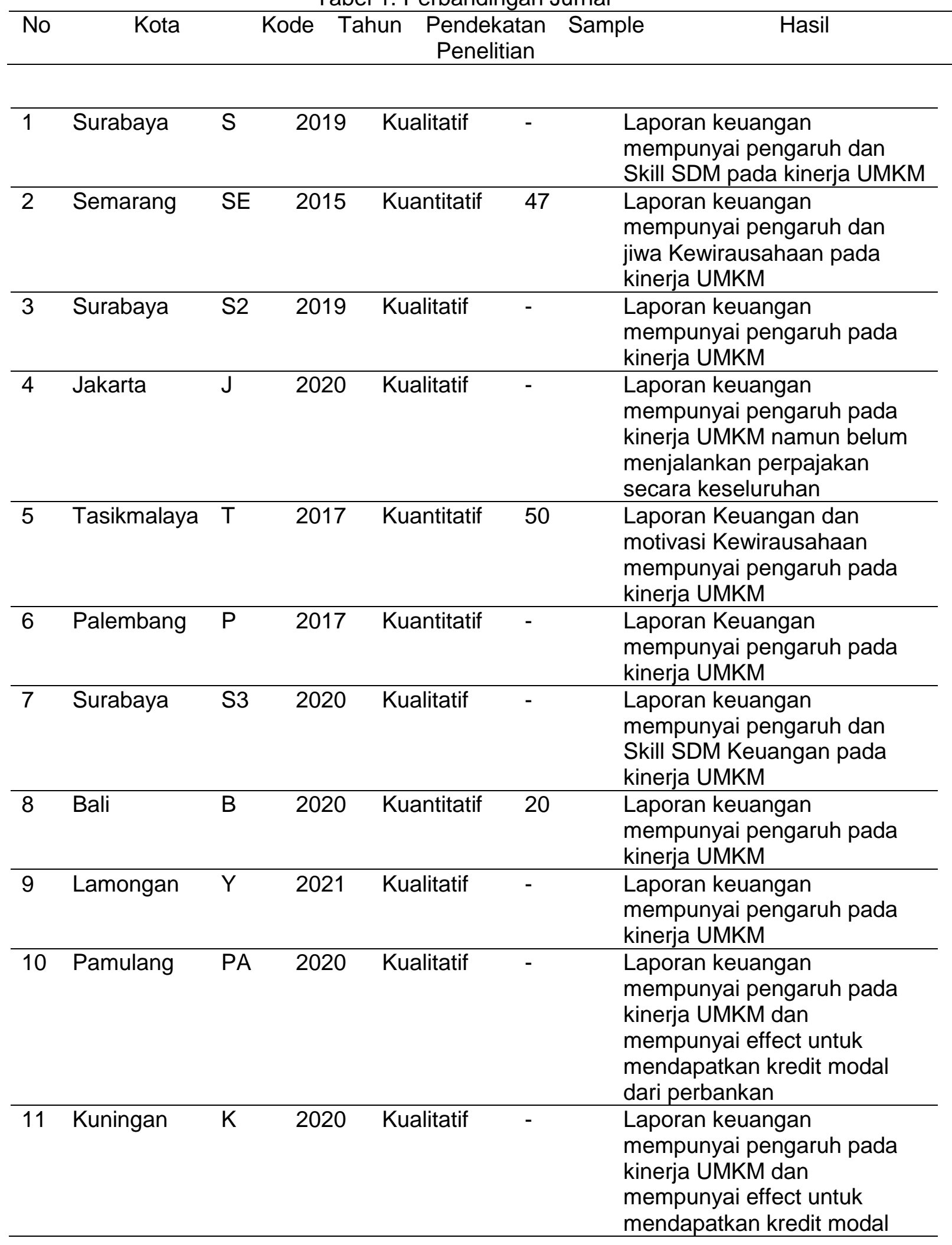


dari perbankan

\begin{tabular}{|c|c|c|c|c|}
\hline 12 Bandung & BA 2016 & Kualitatif & - & $\begin{array}{l}\text { Laporan keuangan } \\
\text { mempunyai pengaruh pada } \\
\text { kinerja UMKM dan } \\
\text { mempunyai effect untuk } \\
\text { mendapatkan kredit modal } \\
\text { dari perbankan }\end{array}$ \\
\hline
\end{tabular}

\section{Cluster Analysis}

Membandingkan istilah-kata yang terdapat pada asal data atau ingin membandingkan kesamaan kata-istilah pada tema-tema output koding yang tersimpan pada nodes. Dalam Analisis klaster ini dapat diukur mengenai korelasi.

Uji korelasi yang digunakan menggunakan Product Pearson Moment yang disediakan di tools NVIVO 12. Analisis hubungan dalam penelitian ini menggunakan analisis korelasi sederhana Pearson Product Moment. Analisis ini dipakai buat mengukur kekuatan hubungan antara dua variabel. Semakin nilai hubungan yg didapat mendekati 1, maka semakin tinggi korelasi antara 2 variabel tersebut. Nilai $r$ yang mendekati nol menyatakan bahwa korelasi yang terdapat antara dua variable sangatlah kecil (Ghozali, 2018). Terlampir dibawah tabel koefesien korelasi:

Tabel 2. Koefisien Korelasi

\begin{tabular}{lc}
\hline \multicolumn{1}{c}{ Interval Koefisien } & Tingkat Hubungan \\
\hline $0.800-1.00$ & Sangat Tinggi \\
\hline $0.600-0.800$ & Kuat \\
\hline $0.400-0.600$ & Cukup \\
\hline $0.200-0.400$ & Rendah \\
\hline $0.00-0.200$ & Sangat Rendah \\
\hline
\end{tabular}

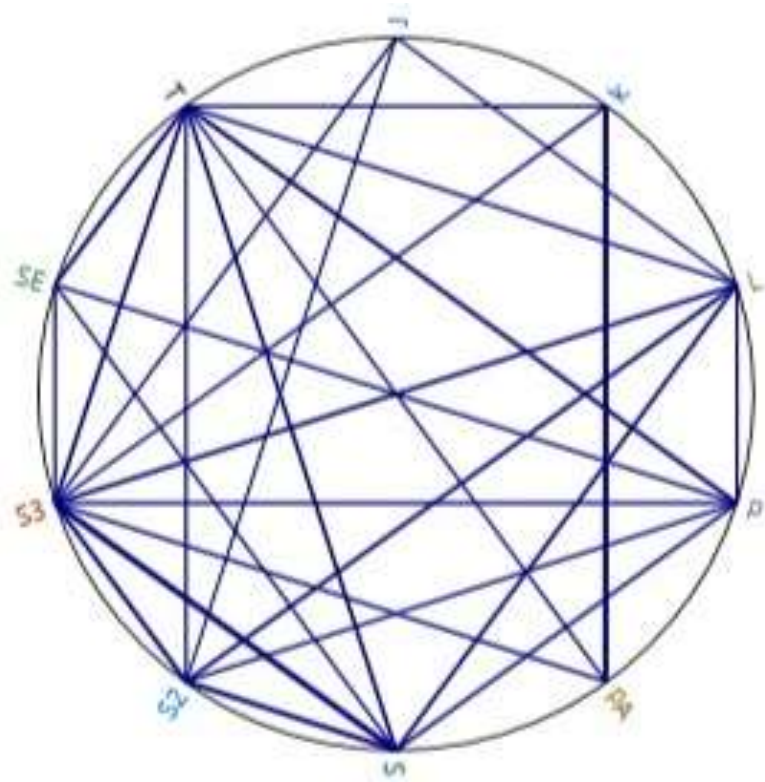

Gambar 1. Analisis Kluster 
Bila dilihat dari gambar diatas masing-masing author mempunyai kesamaan hububungan terutama pada kesamaan kata dimana garis biru menunjukan hubungan yang kuat antara author artikel yang satu dengan yang lainnya. Artinya bahwa semua kata-kata yang ditulis terutama pada bagian yang di koding adalah kota asal, tahun riset, jumlah sampel, jenis riset dan hasil riset mempunyai hubungan yang sama dari paper atau artikel riset yang dibuat oleh author. Perlu diketahui jenis gambaran hasil riset secara angka atau kuantitatif dapat dijelaskan pada tabel summary atau ringkasan mengenai data yang menunjukan hubungan antara kata dari paper atau artikel author satu dengan yang lainnya.

Tabel 3. Pearson Correlation Coefficient Summary

\begin{tabular}{|c|c|c|}
\hline File A & File B & $\begin{array}{l}\text { Pearson } \\
\text { correlation } \\
\text { coefficient }\end{array}$ \\
\hline Files\\
Author\\
S3 & Files\\
Author|IS & 0.840206 \\
\hline Files\\
Author \\
PA & Files\\
Authorl\k & 0.811168 \\
\hline Files\\
Author \\
S2 & Files \\
Author|IS & 0.705992 \\
\hline Files\\
Author $\backslash \backslash S 3$ & Files\\
Author \\
S2 & 0.631803 \\
\hline Files\\
Author \|T & Files \\
Author \IP & 0.611883 \\
\hline Files\\
Author \\
2 & Files $\backslash \backslash$ Author $\backslash \mathrm{L}$ & 0.586667 \\
\hline Files\\
Author \|T & Files\\
Author \\
SE & 0.585394 \\
\hline Files \\
Author $\backslash \backslash T$ & Files\\
Author|IS & 0.568771 \\
\hline Files\\
Author \|T & Files\\
Author \IS3 & 0.568771 \\
\hline Files\\
Author $\backslash \backslash S$ & Files\\
Author \\
L & 0.557614 \\
\hline Files\\
Author \\
3 & Files\\
Author \\
L & 0.557614 \\
\hline Files\\
Author\\
T & Files \\
Author \\
L & 0.486265 \\
\hline Files\\
Author \|T & Files\\
Author \\
S2 & 0.486265 \\
\hline Files\\
Author $\backslash S$ & Files\\
Author \IP & 0.483425 \\
\hline Files\\
Author $\backslash S 3$ & Files \\
Author $\backslash \mathrm{P}$ & 0.483425 \\
\hline Files \\
Author $\backslash \backslash P$ & Files\\
Author\\
L & 0.483333 \\
\hline Files\\
Author \\
S2 & Files\\
Author \IP & 0.483333 \\
\hline Files\\
Author\\
S3 & Files\\
Authorl|k & 0.457616 \\
\hline Files\\
Author\\
S3 & Files\\
Author \\
PA & 0.457616 \\
\hline Files\\
Author\\
SE & Files \\
Author \IP & 0.457466 \\
\hline Files\\
Author $\backslash S 3$ & Files\\
Author \J & 0.437432 \\
\hline Files\\
Author $\backslash S E$ & Files\\
Author|IS & 0.425678 \\
\hline Files\\
Author\\
SE & Files\\
Author \\
S3 & 0.425678 \\
\hline Files\\
Author \IT & Files\\
Authorl\k & 0.419049 \\
\hline Files \\
Author \IT & Files\\
Author \\
PA & 0.419049 \\
\hline Files \\
Author|VL & Files\\
Author|\J & 0.406181 \\
\hline Files\\
Author\\
S2 & Files\\
Author\\
J & 0.406181 \\
\hline
\end{tabular}

Dari tabel diatas yang menunjukan hubungan korelasi sangat tinggi adalah author S3 dengan author $\mathrm{S}$ dan author PA dan author $\mathrm{K}$, kemudian hubungan korelasi kuat adalah author S2 dengan author S, author S3 dengan author S2 dan author $\mathrm{K}$ dengan author $\mathrm{P}$. kemudian masuk dalam kategori cukup sebanyak 22 hubungan antara author yang satu dengan yang lain dimana ditunjukan dengan koifisien antara 0.400 sampai 0.600 . 
Dari tabel diatas belum semuanya dimasukan data terkhusus data korelasi yang mempunyai signifikan koifisien dimana interval koefisiensi antara $0.200-0.400$ sebanyak sebanyak 13 hubungan antara author satu dengan lainnya kemudian sisanya adalah 5.

Bila dilihat dari gambar 1. menunjukan warna biru yang paling dominan dibandingan dengan warna lainnya ini menunjukan dominasi hubungan sangat tinggi, kuat dan cukup lebih besar dibandingkan dengan hubungan interval koefisiensi rendah dan sangat rendah. Dimana prosentase nya adalah 60 dan 40 dari jumlah keseluruhan dari interval koefisien atau tingkat hubungan dari masing-masing data.

\section{Project Map}

Salah satu fitur yg masih ada pada Nvivo 12 buat menampilkan hasil berdasarkan penelitian merupakan berbentuk Map. Istilah yang digunakan sebelumnya pada Nvivo 12 adalah model, namun sekarang sudah diganti dengan kata Map. Project Map: Map yg bersumber menurut coding yg telah dibentuk sebelumnya, baik itu files, Nodes, juga relationships, hal ini mengacu dalam tema-tema hasil koding sehingga dapat melihat/ visualisasi output koding. Adapun output Map atau contoh yang dibentuk merupakan sebagai berikut:

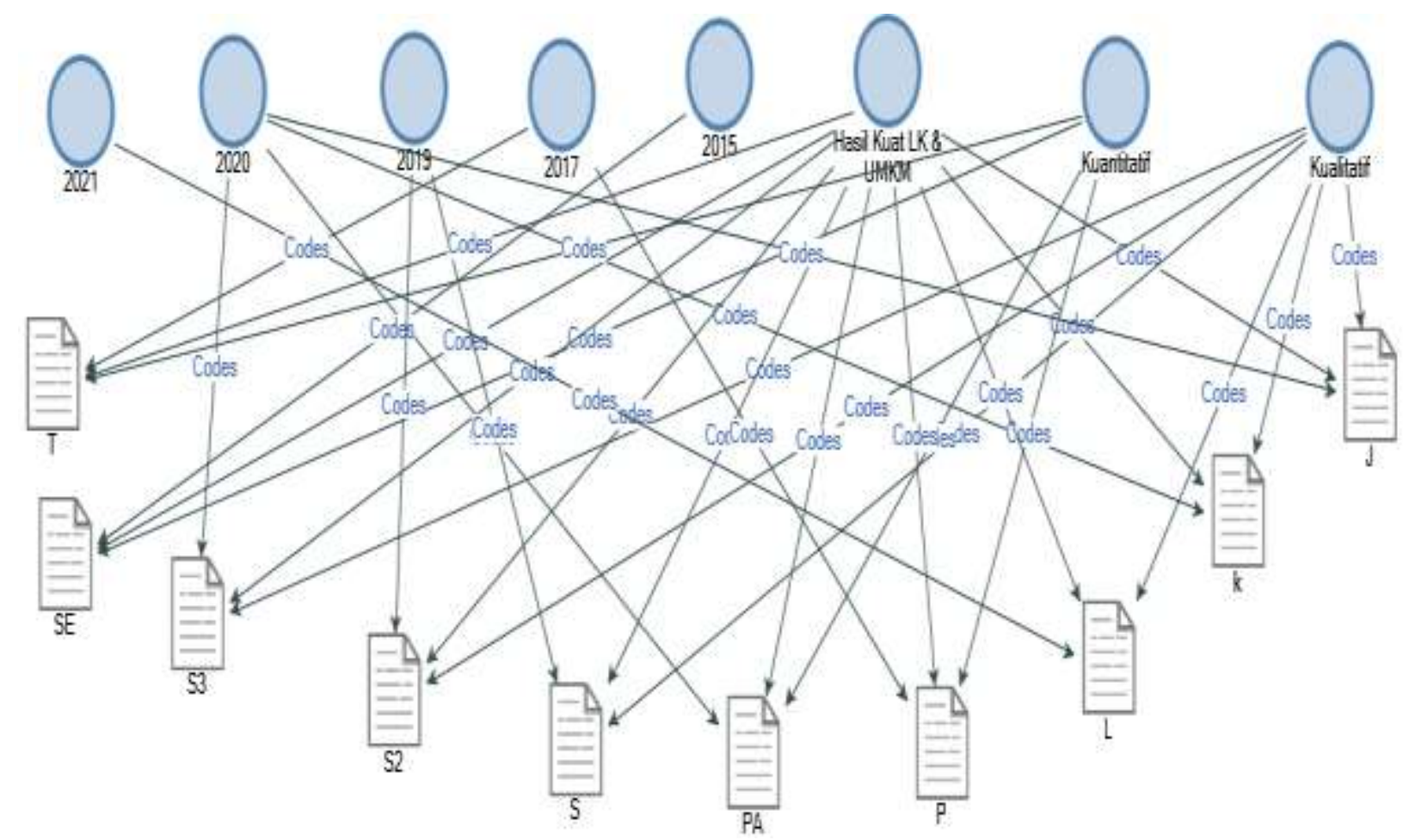

Gambar 2. Project Map Hasil

Dari Map atau model diatas membahas mengenai Project Map Hasil yaitu hubungan yang kuat antara laporan keuangan dengan kinerja UMKM (hasil kuat LK \& UMKM) terhadap tahun riset dan jenis riset. Semua author mempunyai hasil yang sama yaitu kesimpulan bahwa laporan keuangan mempunyai hubungan yang kuat dengan kinerja dari UMKM. Kemudian riset tahun 2021 untuk hasil kuat LK \& UMKM hanya 1 author dimana author L yaitu berlokasi di lamongan dengan jenis pendekatan kualitatif. Tahun 2020 hasil kuat LK \& UMKM sebanyak 4 author dimana jenis pendekatan 1 kuantitatif lokasi Pamulang dan 3 kualitatif dengan lokasi Jakarta, Kuningan dan Surabaya. Tahun 2019 hasil kuat LK \& UMKM sebanyak 2 author dimana jenis pendekatan semuanya adalah kualitatif dimana masing-masing kota adalah surabaya. Tahun 
2017 hasil kuat LK \& UMKM sebanyak 2 author dimana jenis pendekatan 1 kuantitatif di lokasi Tasikmalaya dan 1 kualitatif lokasi di Palembang. Tahun 2015 hasil kuat LK \& UMKM sebanya hanya ada 1 author dimana jenis pendekatan adalah kuantitatif dengan lokasi Surabaya. Seluruh author mempunyai kesamaan dalam hubungan antara laporan keuangan dengan kinerja UMKM yang berada dari masing-masing kota dimana di pulau jawa sebanyak 10 kota dan 1 kota berada di pulau Sumatera. Seluruh author mendominasi tahun penelitian dimulai tahun 2021 sampai dengan tahun 2015 lain halnya dengan peneliti di daerah sumatera yang hanya melakukan penelitian pada tahun 2017 saja. Keunikan peneliti dari luar sumatera adalah peneliti yang melakukan pendekatan jenis riset kuantitatif beda dengan di pulau jawa dimana gabungan antara pendekatan jenis riset kuantitatif dan kualitatif. Map atau model diatas juga didukung dari penelitian sebelumnya yang sama menyimpulkan bahwa laporan keuangan mempunyai hubungan yang kuat dengan kinerja UMKM (Erakipia \& Gamaliel, 2017; Mulyani, 2014; Ningtyas, Si, \& Pusmanu, 2017; Prasetyo, Andayani, \& Sofyan, 2020; Purwanti, 2018b).

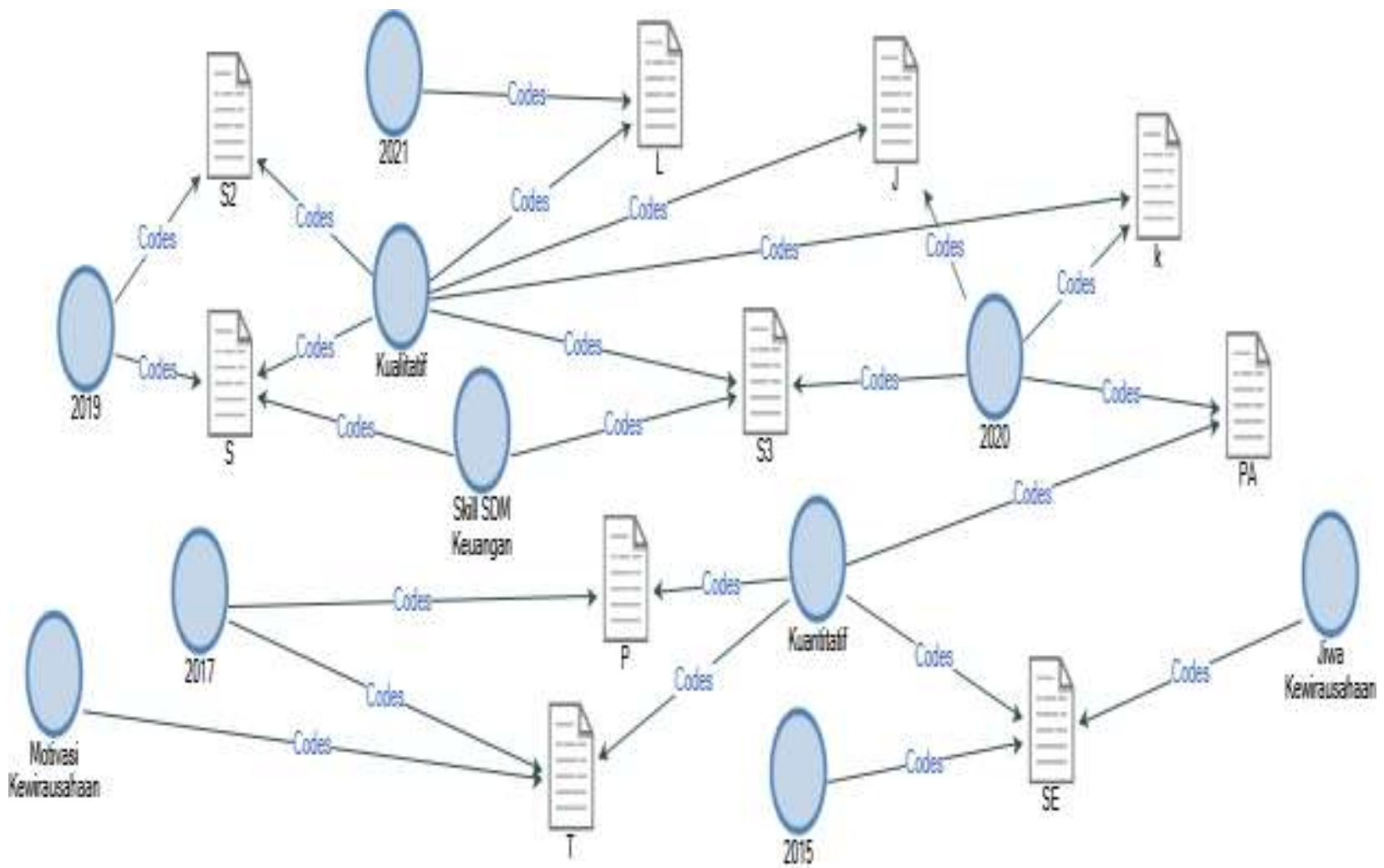

Gambar 3. Project Map Hasil Lain

Dari Map atau model diatas membahas mengenai Project Map Hasil lain yaitu hasil hubungan kuat diluar dari Laporan keuangan dan UMKM dimana Skill SDM (Sumber Daya Manusia) Keuangan, Motivasi Kewirausahaan dan Jenis Kewirausahaan, maksudnya adalah bahwa laporan keuangan bersama-sama dengan hasil lain seperti tersebut diatas mempunyai hubungan dengan kinerja UMKM. Untuk Skill SDM Keuangan sebanyak 2 author berlokasi di Surabaya semuanya dimana tahun penelitian tahun 2019 dan tahun 2020 dengan pendekatan kualitatif semua author tersebut. Untuk Motivasi Kewirausahaan hanya 1 author dimana tahun penelitian tahun 2017 dan jenis pendekatannya adalah kuantitatif. Untuk Jiwa Kewirausahaan hanya 1 author dimana tahun penelitiannya adalah tahun 2015 dan jenis pendekatan riset yang dilakukan adalah kuantitatif. Adapun penelitian lainnya mendukung bahwa Laproan keuangan dan Skill SDM (Sumber Daya Manusia) dan baik itu keuangan dan lainnya mempunyai hubungan yang kuat dengan kinerja UMKM (Atmaja, 2018; L. Bismala, 2016; Lila Bismala \& Handayani, 2014; Khair, 2019; Masriah et al., 2021; Nizar, 2018; Rahmadani, 2020, 2020; Rapih, 2015; Samir \& Larso, 2002; Santoso, Yuwandini, \& Mustaniroh, 2015). Sedangkan untuk 
penelitian lainnya juga mendukung bahwa Motivasi Kewirausahaan secara bersama-sama dengan laporan keuangan mempunyai hubugnan yang kuat terhadap kinerja UMKM (Hambali, 2016; Hamdani, Willy, \& Homan, 2019; Komaludin \& Wahid, 2017; Maulani, Dialysa, \& Prawirasasra, 2016; Muliyanti \& Kaukab, 2020; Nurhayati et al., 2018; Prawirasasra \& Maulani, 2020; Purwanti, 2018b; Riyadi \& Rismawandi, 2016; Wahid, 2017). Sama halnya dengan Jiwa kewirausahan dan laporan keuangan terhadap kinerja UMKM dimana didukung dari penelitian yang sebelumnya sehingga memperkuat hasil dari model tersebut (Hambali, 2016; Ilarrahmah, 2021; Indriyati, 2017b; Komaludin \& Wahid, 2017; Muliyanti \& Kaukab, 2020; Nurlaela, 2015; Praptono \& Andini, 2021; Siagian \& Indra, 2019; Wahid, 2017; Whetyningtyas, 2017).

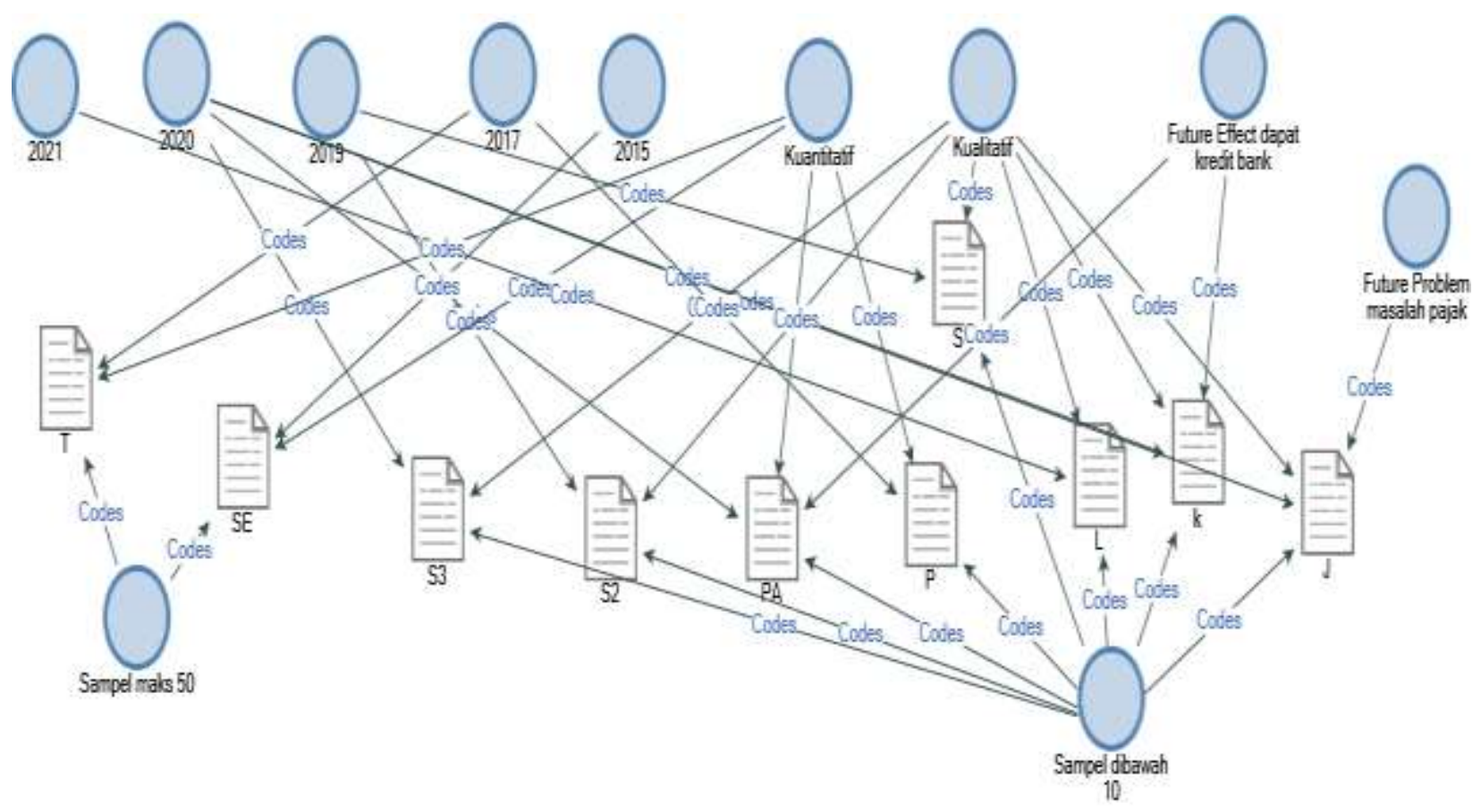

Gambar 4. Project Map Future

Dari Map atau model diatas membahas mengenai Project Map Future yaitu model yang menghubungkan masa depan antara laporan keuangan dan kinerja UMKM, baik itu Future itu masalah atau hal yang menguntungkan. Future terbagi menjadi dua (2) yaitu Future Problem masalah pajak dan Future Effek mendapat kredit bank. Laporan keuangan dan kinerja UMKM ternyata mempunyai efek dua (2) sisi yaitu ada yang baik namun ada juga bermasalah. Future Efek problem masalah pajak hanya ada 1 author yaitu $\mathrm{J}$ berlokasi di Jakarta, tahun penelitiannya 2020, untuk jenis pendekatannya adalah kualitatif dimana jumlah sample berada dibawah 10 responden. Untuk Future Efek mendapatkan kredit bank terdapat 2 author yaitu 1 author berlokasi di kuningan denrgan jenis pendekatan penelitain kualitatif dan dimana sample dibawah 10 responden sedangkan yang satunya adalah berlokasi di Pamulang dengan jenis pendekatan kuantitatif dimana sample berada dibawah 10 responden. Khusus untuk Future Effect mendapatkan kredit bank dari hubungan Laporan keuangan dan kinerja UMKM diperkuat dari beberapa penelitian yang menyimpulkan sama (Indriyati, 2017a; Murti, Trisnadewi, Citraresmi, \& Saputra, 2018; Purwanti, 2018a; Rahmawati \& Puspasari, 2017; Rudiantoro \& Siregar, 2012). 


\section{E. KESIMPULAN}

Hasil kesimpulan yang didapatkan dari model laporan keuangan wirausaha di Indonesia dibagi menjadi beberapa tahapan yaitu antara lain:

1. Cluster Analysis

Dari 12 author dari paper atau artikel yang dimasukan sebagai data sekunder, bahwa 12 author tersebut mempunyai kesamaan korelasi yang dinyatakan dengan interval koifisiensi antara 0.400 - 1.00 bahwa data tersebut Sangat Kuat, Kuat dan Cukup. Hal ini menjelaskan bahwa data yang digunakan adalah valid Karena mempunyai kesamaan kata-kata sehingga menyimpulkan kesamaan yang sama yaitu laporan keuangan mempunyai hubungan yang kuat dengan wirausaha di Indonesia.

2. Permodelan untuk Pola Laporan keuangan wirausaha di Indonesia membentuk tiga pola atau model dimana antara lain:

-Project Map Hasil

Project Map hasil adalah suatu model yang membentuk pola atau model antara Tahun Penelitian, Jenis pendekatan penelitan dan Hasil penelitian.

-Project Map Hasil Lain

Project Map Hasil Lain merupakan suatu model yang membentuk pola atau model antara Tahun penelitian, Jenis pendekatan penelitian dan hasil lain. Hasil lain dimaksud disini adalah faktor lain yang mempengaruhi kinerja UMKM selain dari pada laporan keuangan.

-Project Map Future

Project Map Future adalah suatu model yang membentuk pola atau model antara Tahun penelitian, Jenis pendekatan penelitian, jumlah sample dan Future. Future maksud disini adalah efek masa yang akan datang baik itu bersifat baik atau menghambat.

3. Project Map Hasil, membentuk suatu pola baru yaitu hubungan antara laporan keuangan dan kinerja UMKM serta tahun penelitian dimana rentang waktu sebanyak 6 tahun secara berurutan dari tahun 2015 sampai dengan tahun 2021 hasilnya tetap sama dimana keunikannya adalah gabungan antara penelitian kualitatif dan kuantitatif.

4. Project Map Hasil lain, membentuk suatu pola baru bahwa laporan keuangan dan kinerja UMKM tidak semata hanya 2 variabel tersebut namun ada variabel lain yaitu Skill Keuangan SDM (Sumber Daya Manusia), Jiwa Kewirausahaan dan Motivasi kewirasuahaan yang mempengaruhi dua variabel tersebut dengan rentang waktu penelitian selama 6 tahun dengan jenis pendekatan baik itu kuantitatif maupun kualitatif

5. Project Map Future, membentuk suatu pola atau model baru dimana hubungan antara laporan keuangan dengan kinerja UMKM mempunyak effect future pada masa depan baik itu yang menghambat yaitu mengenai pajak maupun mendukung yaitu mendapat kredit dari perbankan.

6. Dari Cluster Analysis dan 3 Project Map atau Model membantu terutama dalam menentukan kebijakan untuk Kewirausahaan di Indonesia terutama menyangkut laporan keuangan, sehingga kinerja UMKM di Indonesia menjadi lebih baik lagi. 


\section{DAFTAR PUSTAKA}

Atmaja, H. E. (2018). Pentingnya Manajemen Sumber Daya Manusia Untuk Meningkatkan Usaha Kecil Menengah. Jurnal REKOMEN (Riset Ekonomi Manajemen), 2(1), 21-34.

Bismala, L. (2016). Model Manajemen Usaha Mikro Kecil dan Menengah (UMKM) untuk Meningkatkan Efektivitas Usaha Kecil Menengah. Jurnal Entrepreneur Dan Entrepreneurship, 5(1), 19-26.

Bismala, Lila, \& Handayani, S. (2014). Model Manajemen UMKM Berbasis Analisis SWOT. In Prosiding Seminar Nasional PB3I ITM.

Brigham, E., \& M, E. (2013). Financial Management: Theory \& Practice (14 th). Ohio: South Western Publishing.

Carraher, S., \& H, V. A. (2013). The use of financial statements for decision-making by small firms. Journal of Small Business and Entrepreneurship, 26(3), 323-336., 26(3), 323-336.

Erakipia, A. F., \& Gamaliel, H. (2017). Analisis laporan keuangan sebagai dasar penilaian kinerja keuangan pada UMKM Amungme dan Kamoro. Jurnal EMBA: Jurnal Riset Ekonomi, Manajemen, Bisnis Dan Akuntansi, 5(1).

Ghozali, I. (2018). Aplikasi Analisis Multivariate Dengan Program IBM SPSS 25. (Edisi 9). Semarang: Badan Penerbit Universitas Diponegoro.

Hambali, I. R. (2016). PENGARUH MOTIVASI USAHA, LAPORAN KEUANGAN DAN KEMANDIRIAN USAHA TERHADAP KINERJA USAHA UKM DI KOTA GORONTALO. Jurnal Ekonomi Dan Manajemen, 17(1).

Hamdani, D., Willy, S., \& Homan, H. S. (2019). Peningkatan Manajemen Usaha Pada Umkm Opak Desa Bojongkunci Kabupaten Bandung.

Harahap, Y. R. (2014). Kemampuan Menyusun Laporan Keuangan Yang Dimiliki Pelaku UKM Dan Pengaruhnya Tehadap Kinerja UKM. Jurnal Riset Akuntansi Dan Bisnis. Universitas Muhammadiyah Sumatera Utara., 14(1).

Hendrati, I. M. (2010). Latar Belakang Pendidikan, Pelatihan, Dan Jiwa Kewirausahaan Terkait Kinerja Keuangan UKM. Jurnal Riset Ekonomi Dan Bisnis, 10(1 Maret).

Ilarrahmah, M. D. (2021). Pengaruh Kemampuan Menyusun Laporan Keuangan, Literasi Keuangan Dan Penggunaan Teknologi Informasi Terhadap Kinerja UMKM. JPEK (Jurnal Pendidikan Ekonomi Dan Kewirausahaan), 5(1), 51-64.

Indriyati. (2017a). Pengaruh kualitas laporan keuangan dan pemberian kredit terhadap perkembangan UKM Gerabah Kasongan. Prodi Akuntansi Universitas PGRI Yogyakarta.

Indriyati, M. (2017b). Pengaruh kualitas laporan keuangan dan pemberian kredit terhadap perkembangan UKM Gerabah Kasongan. Prodi Akuntansi Universitas PGRI Yogyakarta.

Khair, H. (2019). Kinerja Sumberdaya Organisasi Dalam Perspektif Kewirausahaan Sebagai Upaya Peningkatan Keuntungan Usaha UMKM. In Prosiding Seminar Nasional Kewirausahaan (Vol. 1, pp. 401-406).

Komaludin, A., \& Wahid, N. N. (2017). Analisis Kemampuan Menyusun Laporan Keuangan, Kemampuan Manajerial, Jiwa Kewirausahaan Dan Motivasi Sebagai Faktor Penentu Kinerja Operasional. Jurnal Ekonomi Manajemen, 3(2), 104-113.

Kumar, R. (2011). Research Methodology, a step by step guide for beginners (3rd ed.). Sage Publication. 
Leavy, P. (2017). Research Design- Quantitative, Qualitative, Mixed Methods, Arts-Based, and Community-Based Participatory Research Approaches. New York (NY): The Guilford Press.

Masriah, I., Transiseno, G., Ibrahim, I., Faras, F. A., Sumarna, E., \& Sari, I. R. (2021). PERAN SUMBER DAYA MANUSIA DALAM MENINGKATKAN KINERJA UMKM DI PASAR MODERN INTERMODA BSD PADA MASA PANDEMI COVID 19. Abdi Laksana: Jurnal Pengabdian Kepada Masyarakat, 2(2), 308-313.

Maulani, T. S., Dialysa, F., \& Prawirasasra, K. P. (2016). Pelatihan Pembukuan keuangan sederhana dan motivasi kewirausahaan pada kelompok usaha makanan RW 02 Kelurahan Neglasari Kecamatan Cibeunying Kaler Bandung.

Muliyanti, R., \& Kaukab, M. E. (2020). Analisis Kinerja UMKM pada Market Place Wonosobo Mall. Journal of Economic, Management, Accounting and Technology (JEMATech), 3(2), 154-160.

Mulyani, S. (2014). Faktor-faktor yang mempengaruhi kualitas laporan keuangan pada umkm di kabupaten kudus. Jurnal Dinamika Ekonomi \& Bisnis, 11(2).

Murti, Trisnadewi, Citraresmi, \& Saputra. (2018). SAK ETAP, Kualitas Laporan Keuangan dan Jumlah Kredit yang diterima UMKM. Ekuitas: Jurnal Pendidikan Ekonomi, 6(2), 52-61.

Ningtyas, J. D. A., Si, M., \& Pusmanu, P. (2017). Penyusunan Laporan Keuangan UMKM Berdasarkan Standar Akuntansi Keuangan Entitas Mikro, Kecil dan Menengah (SAKEMKM)(Study Kasus Di UMKM Bintang Malam Pekalongan). Riset \& Jurnal Akuntansi, 2(1), 11-17.

Nizar, M. (2018). Pengaruh sumber daya manusia, permodalan dan pemasaran terhadap kinerja usaha kecil dan menengah sari apel di Kecamatan Tutur. Iqtishoduna: Jurnal Ekonomi Islam, 7(1), 51-69.

Nurhayati, N., Hindarsah, I., Sos, S., Erlangga, H., Sos, S., \& Maun Jamaludin, I. (2018). Pelatihan Pembukuan Di UKM Sumpia Chantika Dewi Cimindi Cimahi. Laporan Program Kepakaran Fisip Unpas Pengabdian Kepada Masyarakat Tahun Akademik 2016/2017, 122.

Nurlaela, S. (2015). Kemampuan Menyusun Laporan Keuangan Usaha Kecil Menengah Pengaruhnya Terhadap Kinerja UKM Kerajinan Gitar Di Kabupten Sukoharjo. Jurnal Paradigma Universitas Islam Batik Surakarta, 12(02), 115906.

Praptono, S., \& Andini, R. (2021). Pengaruh Pengetahuan Akuntansi dan Jiwa Kewirausahaan Pada Penggunaan Informasi Akuntansi dalam Pembuatan Keputusan Investasi pada UMKM Kota Semarang. Jurnal Sains Sosio Humaniora, 5(1), 49-56.

Prasetyo, A., Andayani, E., \& Sofyan, M. (2020). Pembinaan Pelatihan Pembukuan Laporan Keuangan Terhadap Wajib Pajak UMKM Di Jakarta. JURNAL EKONOMI, MANAJEMEN, BISNIS, DAN SOSIAL, 1(1), 34-39.

Prawirasasra, K., \& Maulani, T. S. (2020). Pelatihan Penyusunan Laporan Keuangan Dan Perencanaan Strategi Pemasaranpada Umkm Clothing-Unscarred. Dharma Bhakti Ekuitas, 4(2), 399-403.

Purwanti. (2018a). Analisis pengetahuan laporan keuangan pada umkm industri konveksi di Salatiga. Among Makarti, 10(2).

Purwanti, E. (2018b). Analisis pengetahuan laporan keuangan pada umkm industri konveksi di Salatiga. Among Makarti, 10(2).

Rahmadani, I. N. (2020). Manajemen sumber daya manusia di kampung batik sebagai klaster usaha kecil menengah. Jurnal Digit, 8(2), 232-241. 
Rahmawati, \& Puspasari. (2017). Implementasi SAK ETAP dan Kualitas laporan keuangan UMKM terkait akses modal Perbankan. Jurnal Kajian Akuntansi, 1(1).

Rapih, S. (2015). Analisis pengaruh kompetensi sumber daya manusia, modal sosial dan modal finansial terhadap kinerja UMKM bidang garmen di Kabupaten Klaten. UNS (Sebelas Maret University).

Riyadi, S., \& Rismawandi, R. (2016). MOTIVASI, PENGETAHUAN AKUNTANSI DAN PENERAPAN AKUNTANSI TERHADAP PENGGUNAAN INFORMASI AKUNTANSI (Studi Empiris Pada Usaha Mikro, Kecil dan Menengah (UMKM) di Wilayah Kota Tangerang Selatan, Provinsi Banten). Jurnal Akuntansi Dan Keuangan, 5(1), 80-95.

Rudiantoro, \& Siregar. (2012). Kualitas laporan keuangan umkm serta prospek implementasi SAK ETAP. Jurnal Akuntansi Dan Keuangan Indonesia, 9(1), 1-21.

Hakim, L., Sunardi, N. (2017). Determinant of leverage and it's implication on company value of real estate and property sector listing in IDX period of 2011-2015. Man in India, 97(24), pp. 131-148.

Kadim, A., Sunardi, N \& Husain, T. (2020). The modeling firm's value based on financial ratios, intellectual capital and dividend policy.Accounting, 6(5), 859-870.

Husain, T., \& Sunardi, N. (2020). Firm's Value Prediction Based on Profitability Ratios and Dividend Policy. Finance \& Economics Review, 2(2), 13-26.

Nardi Sunardi Et Al (2020). Determinants of Debt Policy and Company's Performance, International Journal of Economics and Business Administration Volume VIII Issue 4, 204213

Sunardi, N., \& Lesmana, R. (2020). Konsep Icepower (Wiramadu) sebagai Solusi Wirausaha menuju Desa Sejahtra Mandiri (DMS) pada Masa Pandemi Covid-19. JIMF (Jurnal IImiah Manajemen Forkamma), 4(1).

Samir, A., \& Larso, D. (2002). Identifikasi faktor-faktor yang mempengaruhi kinerja UKM catering di Kota Bandung. Journal of Technology Management, 10(2), 120905.

Santoso, I., Yuwandini, D., \& Mustaniroh, S. A. (2015). Pengaruh kredit dan sumber daya manusia terhadap kinerja UMKM agroindustri dengan pemasaran sebagai variabel antara. Jurnal Manajemen \& Agribisnis, 12(3), 174.

Shields, J., \& Shelleman, J. (2011). Management accounting reports in small businesses: Frequency of use and influence of owner locus of control and goals,. Small Business Institute Journal,7(1), 29-51., 7(1), 29-51.

Siagian, A. O., \& Indra, N. (2019). Pengetahuan akuntansi pelaku usaha mikro kecil dan menengah (UMKM) terhadap laporan keuangan. Syntax Literate; Jurnal IImiah Indonesia, 4(12), 17-35.

Wahid, N. N. (2017). Pengaruh kemampuan menyusun laporan keuangan dan motivasi terhadap kinerja ukm di kota tasikmalaya. Jurnal Akuntansi, 12(1), 53-68.

Whetyningtyas, A. (2017). Analisis Pengaruh Kemampuan Menyusun Laporan Keuangan Dan Jiwa Kewirausahaan Terhadap Kinerja Operasional UMKM (Studi Empiris Di Klaster Bordir Dan Konveksi Desa Padurenan, Kecamatan Gebog, Kabupaten Kudus). Prosiding FEB UNTAG Semarang.

Wiratna Sujarweni. (2014). Wiratna Sujarweni. (2014). Metodeologi Penelitian. Yogyakarta: Pustaka Baru Press. 